\title{
Technology Enable Literacy Education through Open and Distance Learning (ODL) in Bangladesh: An Approach
}

\author{
M. S. ALAM ${ }^{1 *}$ AND M. S. ALAM ${ }^{2}$ \\ ${ }^{1}$ Training \& Research, Bangladesh Open University, Gazipur, Bangladesh \\ ${ }^{2}$ School of Agriculture \& Rural Development, Bangladesh Open University, Gazipur, Bangladesh
}

\begin{abstract}
Bangladesh is a densely populated country with a population of 130 million. In Bangladesh the Government and non-Government organizations have taken sufficient initiative to increase the literacy rate but the significant development is yet to achieve. Despite the various steps taken by the Government, the literacy rate stands at 62 percent and, as such, the goal to educate all remains more or less as elusive as ever. Sophisticated technological development in the education world changes the pattern of role and responsibility of learners and teachers and creates more opportunities of learning. Using the virtual image of the Distance Education system there emerges a new horizon of innovativeness with its unlimited possibilities to resolve a very long felt need of eradicating illiteracy and developing human resources (HR) in the globe. Technologies are used in distance education and which can create a forceful impact to accelerate mass literacy, gender balance and also help develop human resources in the pursuit of acquiring different branches of knowledge and skill along with technical and vocational aspects to meet the thirsty need of the time. This paper addresses the issues for developing strategies for technology based literacy programme. It also highlights to identify the parameters for developing an appropriate technology based quality materials for literacy programme.
\end{abstract}

Key words: Appropriate technology, distance education, virtual image, illiteracy, quality material.

\section{BACKGROUND}

Bangladesh has taken up steps for eradication of illiteracy and poverty as its major program which are being carried out with the help of government and non-government organizations. It has achieved remarkable success in the literacy drive increasing the literacy rate from about $40 \%$ in 1995 to $60 \%$ in 2000 . The country has a very large number of NGOs running their activities quite professionally and very effectively. Nearly $42-45 \%$ of development funding is channelled through the NGOs and the Government has, in their policies and functions, played an important role to the NGOs.

A new dimension is added to this by the emergence information age, which is making in-roads in Bangladesh quire fast. Bangladesh Open University is using ICT in many of its activities and is bestowed with quite modern IT facilities. The Bangladesh Open University being the only open education institution in the country offering open school and higher education programme is using distance education method and materials in all its activities of teaching, learning and evaluation.

\footnotetext{
* Corresponding author: Joint Director (Training \& Research), BOU, Tel. 88-02-9291151, email: shafiqul_bou@yahoo.com

(C) 2006 School of Agriculture and Rural Development, Bangladesh Open University, All rights reserved.
} 
The issue of training IT literacy to the literate ones and making them capable in living successfully in the new scenario becomes an important issue both to the Bangladesh Open University and the Government. The issue is of common concern for all the developing countries that have yet to eradicate illiteracy. This is also linked with the digital divide or the classes of inforich and info-poor which needs to be avoided.

This approach is a conceptualization of this need into a ICT enabled literacy program to be carried out under the leadership of the Bangladesh Open University in partnership with GO and NGO.

\section{INTRODUCTION}

The ICT enabled literacy program uses IT and Internet communication quite extensively. The term ICT based limits the activities to the ICT facilitation (ICT centered) and the ICT enabled allows us to consider basically the program and its enablement through ICT (program centered).

What is ODL? ODL is an amalgam of two approaches of education that focus on expanding access to learning. It is characterized by two factors: its philosophy and its use of technology. Its philosophy aims to remove barriers to education and allow students to study what they want, when they want, where they want. The aim of its using technology is to mediate learning.

World wide open education systems have proven themselves as a way for people to gain an education, which would otherwise not be possible. It is well documented in the literature that when compared with conventional forms of education the provision of distance education requires considerable greater planning, larger up-front infrastructure costs, and more complex student and administrative support systems (Lock wood, 1995; Rumble, 1996). In this regard there exists a wealth of theories, principles and practices to guide institutions in the establishment and implementation of open and distance education systems. These not only need to take into account specific student learning needs and circumstances but also student cultural, religious, economic and geographical factors (Keegan, 1993; Evans, 1994).

The increased availability of Information and Communication Technologies (ICTs), that is computers and the interactive communication technologies (video and audio conference, on line education, web), have the potential to solve a number of problems and issues associated with the provision of distance education courses. Particularly for those learning that are largely based on the extended use of print based resources for student learning and provide only limited opportunities for learner - learner and student - staff interaction. As such, open and distance learning is becoming increasingly important in making education more mass-oriented and responsive to need with its ability to reach learners in remote areas and address the education needs of children, adults, the deprived and the disadvantaged alike.

Taking in consideration of all advantages of ODL and ICT, this approach for providing literacy education using ICT through distance mode is taken for implementation for eradication of illiteracy from the country within shortest possible time.

\section{CONCEPT OF LITERACY}

The concept of literacy has changed radically. It started with the idea of survival skills of reading, writing and arithmetic, the 3 Rs. The minimum levels of these skills are often well defined in various literacy programs adopted. In Bangladesh there are two levels adopted; in one simple reading, writing and elementary counting will pass one as literate, and in another achievement of the $5^{\text {th }}$ standard of the primary education is expected.

The literacy is defined in many ways. It changed its focus from certain levels of skill development in $3 R$ to functionality that will enable one to work and live effectively in the community. The literacy requires ability to apply skills and a set of basic knowledge to live as an informed citizen in a community.

We are currently undergoing a transformation from Industrial Society to the Information Society. The literacy needs further redefinition in terms of new competencies and skills necessary to live and work effectively in the Information society. One approach adopted by many is to impart 4 
Rs, the fourth $\mathrm{R}$ being the computer or IT literacy. The computer literacy is requited by all, educated, literate and illiterate.

Literacy has a liberating value, which serves truly literate to socialize in a society of emerging diversity and mobility, to motivate to participate in community and national affairs and to broaden his/ her worldview. With the process of globalization and liberalization sweeping the whole world the literacy program acquires great importance. The program should cultivate those competencies and skills that make one capable of learning to know, to do, to live together and to be (the four pillars of education). ICT enabled program should aim at strengthening related competencies and skills of using IT skills to learn continuously and to helping solve the problems of life and work in the emerging society.

\section{SCENARIO FOR THE LITERACY AND IT EDUCATION IN BANGLADESH}

The Government of Bangladesh has adopted a policy and declared IT as the thrust sector of the economy of the country. It has created favorable atmosphere by withdrawing customs duty and VAT from imported hardware and software. The Government of Bangladesh is supporting computer science departments of the universities and promoting IT education and development at various levels. The government has formulated an IT policy to promote rapid growth of IT in Bangladesh.

Many private IT education institutions are mushrooming in the country. Youth is aspiring to build career in this field and is ready to pay high fee for good and branded education.

One of the major issues in the human resource development is the IT access to poor and illiterate; and is likely to create great divide (Digital Divide) between information-rich and information-poor.

The government started an adult literacy program in 1980, in the name of Mass Education Program (MEP). It had a halting progress in the 1980s and was merged into INFEP (Integrated Non-Formal Education Program) in 1991-92. Nation Plan of Action (NPA I) projections saw the 15+ adult population rise from 61.6 million in 1991 to 75.6 million in 2000. The adult literacy rate was 34.6 percent or 21.3 million literate adults in1991. NPA I proposed to raise the adult literacy rate to 62 percent and number of literate adults to 46.9 million by 2000 through Adult Literacy program for 15-45 age group. NPA I objective was to "Provide illiterate adults opportunities for developing reading, writing and understanding the contents and also developing need-based functional/vocational skills as well as creating opportunities for them to continue to learn, with special focus on women's learning." (NPA II, 2003)

The NGO movement in the country is very strong and over 1300 NGOs are working in various areas of development. In fact the Govt. of Bangladesh accords definite role to volunteerism in social mobilization and development. As a consequence the Government. and NGO efforts, the literacy rate has increased from $40 \%$ in 1995 to $60 \%$ in 2000. The Nation is planning to raise it to over $90 \%$ in the next $10-15$ years.

\section{DISTANCE LEARNING AND CONVERGENT TECHNOLOGIES}

\section{Video Conferencing}

To achieve effective delivery of training courses to learners living in remote rural areas, training provider should consider several key factors. Firstly, they must provide high quality, easy and understandable material. Secondly, due to lack of physical staff presence, the material should be interactive. Lastly tutorial staff must offer regular, high quality learning support. Arguably the most effective method of tutorial provision within open distance learning (ODL) is video conferencing. Video conferencing may use for training of literacy trainers located in remote area.

\section{Digital Satellite TV}

Satellites and their most popular deliverable, television, are now a familiar feature of life in industrial societies. Most individuals by now are aware that global information can be easily accessed by the simple installation of a satellite antenna dish and a decoder /receiver connected to a domestic television screen. Satellite TV can be used for literacy training providing literacy programs with proper episodes using animation and pictures. 


\section{Computer Mediated Communication (CMC)}

Computer mediated communication refers to any written interaction that is generated and transmitted with the use of computer technology. It can provide a number of facilities including mail and real time chat capabilities which can be used to deliver instruction or to conduct online seminars and collaborative working on documents and projects. CMC can also be used to facilitate group discussions and to enable interactions between tutors and learners, irrespective of time and place constraints. It has been claimed that $\mathrm{CMC}$ can be used as a powerful tool for group communication and cooperative learning. This can be used for managing and coordinating literacy program.

\section{The Internet and World Wide Web (WWW)}

The Internet is a dynamic architecture consisting of a world wide network of computers, databases and users. It is the sum of all the public and privately owned computer networks currently connected together. It is composed of essentially five things: Computers, connections, software, data and people. WWW can be used providing literacy materials in respective web page and illiterate people can see and learn with the help of tutors.

\section{STRATEGIES FOR TECHNOLOGY BASED LITERACY PROGRAM IN BANGLADESH}

There are no such type of institutions in Bangladesh that cater literacy training through ICT in Bangladesh. Bangladesh Open University is the only distance education in Bangladesh, which is offering its program through distance mode using technology. It has wide range of network throughout the country with its 12 Regional Resources Centres, 80 Local Centres and 1300 Tutorial Centres. An initiative may be taken by BOU to provide literacy training through its network using technology. The following strategies may be considered to provide literacy training through ICT in Bangladesh.

- $\quad$ Bangladesh Open University (BOU) may take the key role to provide literacy training through ICT on the basis of its past experiences in providing other distance education programmes through ICT.

- Partnerships may be developed between NGO's and the Government institutions/ organizations at local and national level to foster and delivery of literacy programme through ICT.

- $\quad$ BOU can develop and integrate its own strengths in supporting and promoting the programmes of literacy.

- ICT based community learning centres may be established in the BOU's network system.

- IT based teaching and learning systems that is most appropriate for the literacy programme should be developed.

- ICT based approach, system, method and learning resources will have to develop to support the literacy programme.

- Materials that will fulfill the need and perceived needs of the learners and communities should be developed.

- During the transitional stage appropriate mix of the existing and available technologies should be applied, by keeping all the time in view the transformation to the utilization of newer and emerging ICT's. The ICTs should be appropriate, economical, and have user friendly linkages and intimate interactivities and remain in line with the process of globalization.

- The effect of literacy, when it leads to real learning, on quality of life and poverty is indirect and long-term. The effect can be hastened and benefits increased when literacy plus non-formal learning is linked with other development activities such as primary health care, family planning, agricultural extension and formation of self help groups. The impact on poverty can become tangible if access to credit, entrepreneurial advice and help with marketing and similar support are available to learners. 


\section{DEVELOPMENT OF LEARNING RESOURCES}

The learning resources will consist of

- Learning materials will be in the form of print, audio and video cassettes and multi-media materials. The electronic materials could in the format of $C D$, tapes convenient for delivery.

- Electronic materials could also be put on the web and made accessible to learners. Content of the materials could be covering the curriculum proposed and supportive, and enrichment materials needed to support the learners in their learning aspirations.

- Expert panel of teachers and domain experts giving services on the Internet will also form learning resources.

a) Approach to the development of the materials:

Strategy proposed is not to re-discover wheel but to start from the available best teaching learning materials and adopt/adapt/transform it to the ICT enabled formats.

\section{b) Steps for materials development:}

- Identification of literacy materials of quality and relevance.

- Identification of parts and units that could be transformed into IT enabled learning materials as a supplementary and complementary material in IT based education. This will involve identification of the media (CD-multi-media, audio, video, print) as well as expanded learning objectives.

- Use of ICT based materials in the teaching and learning programmes along with a feedback on the effectiveness and efficiency of the materials.

- Transformation of the ICT based material for using it in an alternative mode of teaching learning.

- Using the ICT based materials in the alternative mode for a literacy group learning entirely through IT mode.

This approach allows us to have finally three modes, traditional print based literacy education (currently in practice), print supplemented by ICT based teaching-learning materials and entirely ICT enabled teaching and learning materials.

Trying the learning materials in three delivery modes will also give us the comparative results in utility and effectiveness of the ICT enabled teaching and learning both in costs and efficiency in learning.

c) ICT enabled content development:

Following mechanisms (based on course team approach usually adopted in the Open University system) are proposed for the development of learning resources.

a) Development of the learning materials will include:

- Development of web site with supportive and enrichment materials.

- Web sites of some partner institutions that would add value to the literacy and post literacy programs.

- Organization of expert learning services and FAQs and Answers on the basis of answers of the experts.

b) The multimedia production will be needed.

c) Participation of multi media, audio and video production teams, self-instructional editing, and assessment of the usefulness of the materials to the target group, the following tasks should be entrusted

- CD- MM production

- Audio-visual production Content Editing, need assessment, ascertaining relevance, usefulness and effectiveness of the materials and methods of ICT

- Enabled teaching and learning relevance 


\section{DELIVERY OF LITERACY PROGRAM}

Delivery of the literacy programs of various types needs an approach of participatory and active learning since learners have to concentrate not only on learning but also applying it in various life and work situations. It is essential to have community participation, which continuously identifies their needs and gives feed back to make the program relevant and effective in their development process.

Bangladesh is having many national and local NGOs which have already developed such learning systems and have created motivation by giving financial credit for income generating and enhancing activities. They are therefore ideal partners in the development and delivery of the literacy program. Each Community Learning Centre (CLC) should, therefore, identify such a partner who will do the social mobilization work and literacy teaching. The teacher/social worker from the partner NGOS/GO should be oriented to help learners in the process of learning with the help of ICT.

The communication and delivery of information will be through

- Network communication through web site of the program and Internet/e-mail.

- Electronic media communication through CDs/DVDs, Audio and Video cassettes.

- $\quad$ Electronic broadcast communication through radio and TV.

- Print based communication through books, charts etc.

- Face-to-face communication in a classroom.

\section{ORGANIZATION OF ACTIVITIES FOR LITERACY PROGRAM}

Community Learning Centre will be established for providing literacy program using ICT. In each Community Learning Centre, Adult Literacy program will be organized by a literacy/social worker belonging to a local/national NGO. This will involve conventional literacy teaching-learning, ICT based teaching - learning and a mix of the two designed to evolve appropriate model of effective and efficient literacy teaching-learning. Computer literacy to the illiterate and neo-literate will be taught by the personnel at the CLC.

\section{CONCLUSION}

Technologies for distance learning are developing fast, especially in delivery systems and learning support network infrastructures. In order to achieve the required levels of Quality, Access and Cost that users and providers expect, it is likely that solutions for delivery of distance learning courses will involve an appropriate combination of computer and network technologies. In particular it seems likely that a combination of satellite and terrestrial networks will be a key factor in the delivery of effective distance learning literacy courses.

It is concluded from the approach that literacy program can be delivered using ICT in Bangladesh. Bangladesh Open University can play provital role in launching this ICT enabled literacy program using its vast infrastructure and existing ICT facilities. The program should first implement on pilot basis then this can be replicated in larger scale taking into consideration its advantages and disadvantages in next program.

\section{LITERATURE CITED}

Lookwood, F. (ed). 1995. Open and distance learning today, London: Routledge.

NPA II, 2003. Education for ALL: National Plan of Action, 2003-2015, Ministry of Education, Government of the People's Republic of Bangladesh.

Rumble, G. 1986. The Planning and Management of Distance Education, London: Croom Helm.

Erans, T. 1994. Understanding Learners in Open and Distance Education, London: Routledge.

Keegan, D. (ed). 1993. Theoretical Principles of Distance Education, London, Kogan page. 